\title{
E1 Pyruvate Dehydrogenase Deficiency in a Child with Motor Neuropathy
}

\author{
GISĖLE BONNE, CHANTAL BENELLI, LINDA DE MEIRLEIR, WILLY LISSENS, \\ MICHĖLE CHAUSSAIN, MONIQUE DIRY, JEAN-PIERRE CLOT, GERARD PONSOT, \\ VALĖRIE GEOFFROY, JEAN-PAUL LEROUX, AND CECILE MARSAC
}

INSERM U 75, Faculté Necker, 75015 Paris, France [G.B., M.D., J-P.L., C.M.], INSERM U 30, Hôpital

Necker, 75015 Paris, France [C.B., J-P.C., V.G.]; Laboratoire de Génétique, Vrije Université Bruxelles, 1090 Bruxelles, Belgium [L.D.M., W.L.]; and Hôpital Saint Vincent de Paul, 75014 Paris, France [M.C., G.P.]

\begin{abstract}
We report the case of a boy who developed a motor neuropathy during infectious episodes at $18 \mathrm{mo}$ and $3 y$ of age. When he was $7 y$ old, he suffered persistent weakness and areflexia; his resting lactate and pyruvate values were $3.65 \mathrm{mM}$ and $398 \mu \mathrm{M}$, respectively (controls: $1.1 \pm 0.3 \mathrm{mM}$ and $90 \pm 22 \mu \mathrm{M})$, and an exercise test demonstrated a lactic acidosis $(13.6 \mathrm{mM}$; controls: $6.4 \pm$ $1.3 \mathrm{mM})$ with a high pyruvate level $(537 \mu \mathrm{M}$; controls: 176 $\pm 15 \mu \mathrm{M})$ and a low lactate/pyruvate ratio (24.2; controls: $35 \pm 2$ ). The results of polarographic studies on muscle mitochondria suggested a defect in pyruvate oxidation (pyruvate $17 \mathrm{ng}$ atom $\mathrm{O} / \mathrm{min} / \mathrm{mg}$ protein; controls: $115 \pm 42$ ), whereas glutamate, palmitoylcarnitine, and succinate were good respiratory substrates. The activity of total pyruvate dehydrogenase complex (PDHC) in muscle mitochondria and in fresh mononuclear cells was markedly decreased (9.7 and $0.054 \mathrm{nmol}{ }^{14} \mathrm{CO}_{2} / \mathrm{min} / \mathrm{mg}$ protein, respectively; controls: $123 \pm 4.5$ and $0.733 \pm 0.03$, respectively). Immunochemical analysis in muscle mitochondria demonstrated an absence of the $\alpha$ and $\beta$ E1 PDHC subunits. After $2 \mathrm{y}$ of treatment with $500 \mathrm{mg} / \mathrm{d}$ thiamine, the patient was clinically improved. A genetic study of the main regions of mutations (exon 10 and 11) in the $X$ chromosome encoding for the $\mathrm{E} 1 \alpha$ subunit of PDHC did not show any mutation. These data indicate that, although genetically different, this case enters in a very rare category of patients with PDHC deficiency without cerebral dysfunction and improved by thiamine $+\mathrm{L}$-carnitine therapy. (Pediatr Res 33: 284-288, 1993)
\end{abstract}

\section{Abbreviations}

PDH, pyruvate dehydrogenase

PDHC, pyruvate dehydrogenase complex

PDH E1, pyruvate decarboxylase

PDH E2, dihydrolipoyl transacetylase

PDH E3, dihydrolipoyl dehydrogenase

RCR, respiratory control ratio

TPP, thiamine pyrophosphate

PMC, peripheral mononuclear cells

$\mathrm{L} / \mathrm{P}$ ratio, lactate to pyruvate ratio

$\mathrm{VO}_{2}$, oxygen consumption

The mammalian PDHC catalyzes the oxidative decarboxylation of pyruvate to acetyl $\mathrm{CoA}$ and thereby plays an essential

Received May 8, 1992; accepted October 12, 1992.

Correspondence and reprint requests: Gisèle Bonne, INSERM U 75, Faculté Necker, 156 rue de Vaugirard, 75015 Paris, France.

Supported by the AFM (Association Française contre les Myopathies): a fellowship to V.G. and grants to C.M. role in aerobic energy metabolism (1). It consists of multiple copies of three catalytic enzymes: PDH E1, which is composed of two $\alpha$ and two $\beta$ subunits and uses thiamine pyrophosphate as a coenzyme, PDH E2, and PDH E3. An additional protein X is involved in the linkage of the different subunits (2). Two regulatory enzymes (PDH kinase and $\mathrm{PDH}$ phosphatase) catalyze the interconversion of the active, dephosphorylated and the inactive, phosphorylated forms of PDH E1 (3). The clinical spectrum of human PDHC deficiency is extremely broad, ranging from lactic acidosis to chronic neurologic dysfunction without severe lactic acidosis, but cerebral dysfunction is a characteristic feature in most cases $(4,5)$. Defects in PDHC activity are usually documented with skin fibroblast cultures (6-8). The studies at the protein level have shown that defects in the E1 component are the most frequent (4) and, in the majority of the cases, are located in the E1 $\alpha$ subunit. The $\mathrm{E} 1 \alpha$ gene has been localized to the p22.1 to p22.2 region of the X chromosome (9). This gene is approximately $17 \mathrm{kbp}$ long and contains 11 exons (10). Until now, mutations in exon 10 and 11 have been described in PDH E1 $\alpha$ deficiency (11-13).

We have investigated a new case of an infant with a motor neuropathy and a severe PDHC deficiency in lymphocytes and muscle. The absence of cerebral dysfunction contrasts with the severity of the biochemical defect. An absence of immunoreactivity of the $\mathrm{E} 1 \alpha$ and $\mathrm{E} 1 \beta$ subunits was found in muscle mitochondria. However, the sequencing of exon 10 and exon 11 of PDH E1 $\alpha$ gene showed no mutation. A thiamine therapy improved the clinical and biochemical features after 2 y of treatment with thiamine $500 \mathrm{mg} / \mathrm{d}$.

\section{MATERIALS AND METHODS}

Chemicals. Ficoll-Paque was from Pharmacia (Uppsala, Sweden). Sepracell-MN was from Sepratech Corp. (Oklahoma City, OK). Hank's medium was from Eurobio (Paris, France). Bovine albumin cocarboxylase and NAD were obtained from Sigma Chemical Co. (St. Louis, MO). CoA and phosphotransacetylase were from Boehringer (Mannheim, Germany). $1-{ }^{14} \mathrm{C}$-pyruvic acid $(9.8 \mathrm{mCi} / \mathrm{mmol})$ and hyamine hydroxide were from New England Nuclear (Boston, MA). Other chemicals were from E. Merck (Darmstadt, Germany) or Sigma. ${ }^{35}$ S-labeled goat antirabbit antibodies $(500 \mathrm{Ci} / \mathrm{mmol})$ were from Amersham (Paris, France).

Case Report. The proband was born at $40 \mathrm{wk}$ after a normal gestation; he was the youngest of four children of a 32-y-old woman and an unrelated 36-y-old man. He was first seen at 18 mo of age with abnormalities of gait and frequent falls. These symptoms developed $8 \mathrm{~d}$ after a sore throat and vaccination against diphtheria, tetanus, pertussis, and poliomyelitis. There was a bilateral and distal lower limb weakness, but no sensory symptoms or pain. The deep tendon reflexes were absent, and 
there was no plantar response. The recovery was complete within $2 \mathrm{wk}$, but areflexia persisted. The cerebrospinal fluid and electrodiagnostic studies during this first attack were normal. A similar episode recurred at $3 \mathrm{y}$ of age after an attack of bronchitis. There were no cerebral or cellular symptoms. Echocardiography, computed tomography scan, and magnetic resonance imaging of the brain were normal. Amino acid and organic acid chromatograms were normal. The electrodiagnostic studies showed mildly reduced motor nerve conduction velocity $(38 \mathrm{~m} / \mathrm{s})$, absent sensory nerve conduction velocity, denervation, and absent somatosensory-evoked responses. A muscle biopsy was performed for morphology and histochemistry analysis. Muscle histochemical studies showed a marked fiber type grouping with no denervation atrophy, suggesting chronic denervation with renervation. Modified Gomori trichrome staining did not show ragged red fibers. These results were in favor of a neuroaxonal neuropathy. At 7 y of age, because of persistent abnormal weakness and frequent falls, the patient was hospitalized a third time. He showed persistent areflexia and generalized muscular atrophy outside an infectious context. The blood lactate and pyruvate concentrations were elevated in the fed state $(3.8 \mathrm{mM}$ and $241 \mu \mathrm{M}$, respectively). At this time, a second muscle biopsy was performed for biochemical studies. An exercise test was also carried out to follow the dynamic metabolic parameters. At this time, a PDHC deficiency was suspected, and a treatment was started associating oral thiamine $500 \mathrm{mg}$ and L-carnitine $200 \mathrm{mg} / \mathrm{d}$, to fully activate the residual PDHC activity (14). After 2 y of treatment, the only persisting symptoms were areflexia and moderate atrophy of the proximal muscles of the lower limbs. A second exercise test, performed after 1 y of treatment, demonstrated the efficiency of the thiamine therapy on the metabolic parameters.

Biologic and Biochemical Studies. Exercise test. The exercise test was performed on an Astrand children's cycle ergometer (Monark-Crescent, Varberg, Sweden). Control children exercised first at $12.5 \mathrm{~W}$ for $2 \mathrm{~min}$. Then, the power was increased $12.5 \mathrm{~W}$ every 2 min until the maximum power each child was able to sustain was reached (his heart rate increased continuously and reached 180 beats/min at this level of exercise). At rest and during exercise, the respiratory parameters measured were ventilation $\mathrm{VO}_{2}, \mathrm{CO}_{2}$ production $\left(\mathrm{VCO}_{2}\right)$, and respiratory exchange ratio $\left(\mathrm{VCO}_{2} / \mathrm{VO}_{2}\right)$, using a Gould 9000 cardiopulmonary exercise system (Gould 8000 IV metabolic cart, Dayton, OH). Venous (antecubital) blood was collected at rest and at the end of the exercise test. Lactate and pyruvate concentrations were determined in perchloric acid extracts of whole blood, and the L/P ratio was calculated.

Cell preparation. PMC from heparinized peripheral blood were separated at room temperature on a Ficoll-Paque gradient as described by Boyum (15). Total PMC collected at the interface of the Ficoll-Paque density gradient were washed three times in Hank's medium containing $0.2 \%$ BSA. The viability of the cells was 94 to $97 \%$ as estimated by trypan blue exclusion. Total PMC were counted in a hemocytometer and adjusted to $8 \cdot 10^{6}$ cells/ $\mathrm{mL}$.

Cell suspension was diluted in $100 \mathrm{mM}$ potassium phosphate, pH 7.4, 2 mM EDTA, and $1 \mathrm{mM} \mathrm{DTT}$ (buffer A) and centrifuged at $1000 \times g$ for $20 \mathrm{~s}$. The pellets were washed and resuspended in the corresponding buffer A. Cell suspensions were disrupted by sonication before PDH assay.

Preparation of muscle mitochondria. An open biopsy of the quadriceps femoris $(0.7 \mathrm{~g})$ of the patient was performed under local anesthesia with the written consent of the parents. Mitochondria were isolated according to Morgan-Hughes et al. (16) with minor modifications (17).

Polarographic studies with purified mitochondria. The freshly isolated mitochondria were incubated with different substrates as previously described (17). The state $3 /$ state 4 transitions were induced with small additions $(250 \mu \mathrm{M})$ of $\mathrm{ADP}$. $\mathrm{VO}_{2}$, expressed in $\mathrm{ng}$ atoms $\mathrm{O} / \mathrm{min} / \mathrm{mg}$ protein, and the values of the $\mathrm{RCR}$ were calculated $[\mathrm{RCR}=$ rate of ADP-stimulated respiration (state 3 ) divided by the respiration rate after transformation of ADP into ATP (state 4)].

Enzymatic assays. PDH activity was assayed as the release of ${ }^{14} \mathrm{CO}_{2}$ from $1-{ }^{14} \mathrm{C}$-pyruvic acid according to Seals and Jarett (18) with minor modifications, as previously described (19). Mitochondrial proteins $(10 \mu \mathrm{g})$ or a cell extract (obtained from $10^{6}$ cells) were preincubated in a mixture containing $0.5 \mathrm{mM} \mathrm{CaCl} 2$ and $10 \mathrm{mM} \mathrm{MgCl}_{2}$ for $10 \mathrm{~min}$ at $37^{\circ} \mathrm{C}$ (fully activated $\mathrm{PDH}$ ). The PDH assay was then initiated as described by Clot et al. (19).

Succinate cytochrome $c$ reductase, cytochrome $c$ oxidase, and citrate synthase activities were measured on freshly isolated mitochondria by spectrophotometric methods $(16,20)$.

Immunologic Studies. Preparation of antiserum against bovine heart PDHC. PDH $(0.1 \mathrm{mg}$, bovine heart, Sigma) was dissolved in $1 \mathrm{~mL}$ of PBS, pH 7.4, mixed with an equal volume of Freund's complete adjuvant, and injected intradermally into the back of a New Zealand White rabbit. Injections were repeated at 2-wk intervals. Blood was collected from a marginal ear vein after the third injection and serum stored at $-80^{\circ} \mathrm{C}$

Western blot analysis. Protein electrophoresis of muscle mitochondria from two controls and the patient (10- $\mu \mathrm{g}$ proteins) and purified bovine heart PDHC $(2.5 \mu \mathrm{g})$ was carried out on $15 \%$ polyacrylamide gel (SDS-PAGE) as described by Laemmli (21). Proteins were electrophoretically transferred onto a nitrocellulose membrane $(0.1-\mu \mathrm{m}$ pore size, Schleicher and Shüll, Dassel, Germany) with $0.8 \mathrm{~mA} / \mathrm{cm}^{2}$ for $1 \mathrm{~h}$. After saturation (2 h) in PBS-milk (5\% wt/vol), the membrane was incubated overnight with anti-PDH antiserum diluted at $1 / 50$ in PBS-milk. Three washings of $10 \mathrm{~min}$ each with PBS-Tween $20(0.1 \% \mathrm{vol} /$ vol) were carried out. This followed incubation of $30 \mathrm{~min}$ with ${ }^{35} \mathrm{~S}$-labeled goat anti-rabbit antibody $(0.3 \mu \mathrm{Ci} / \mathrm{mL})$. Then, after three washings of $10 \mathrm{~min}$ in PBS-Tween 20, the nitrocellulose was exposed to an X-ray film (Industrex-AX Kodak, Rochester, NY).

Genetic Analysis of PDH E1 $\alpha$ Exons 10 and 11 . Exons 10 and 11 of the human PDH E1 $\alpha$ gene were amplified from $0.5 \mu \mathrm{g}$ of genomic DNA (22) by the polymerase chain reaction (23). Synthetic oligonucleotide primers for exon 10 were PDH10i5 (5'-TTTCATCACGCCGTCCTTGC-3'), and PDH10i3 (5'CACTTCCACATCAATTTCCTAA-3'); for exon 11 they were PDH1li5 (5'-AAAGAGAATGTGGTCGTTGTCC-3'), and LD3' (5'-GTCTGGTAGCCCCCTGCAGG-3').

A cycle consisted of denaturation at $94^{\circ} \mathrm{C}$ for $60 \mathrm{~s}$; annealing at $57^{\circ} \mathrm{C}$ for $60 \mathrm{~s}$ (for exon 10 ) or at $55^{\circ} \mathrm{C}$ for $45 \mathrm{~s}$ (for exon 11 ) and extension at $72^{\circ} \mathrm{C}$ for $120 \mathrm{~s}$ (for exon 10) or $60 \mathrm{~s}$ (for exon 11). After 30 cycles, the amplified fragments were subcloned into plasmid pUC18 for sequencing. DNA sequencing was performed by Sanger's method (24), using a T7 polymerase sequencing kit (Pharmacia Molecular Biology Div., Uppsala, Sweden).

\section{RESULTS}

Exercise Test. Pre- and posttreatment respiratory and metabolic results are reported in Table 1.

Pretreatment results. Resting heart rate was 108 beats/min; heart rate increased continuously during the test, reaching 180 beats/min at the end of the 12.5-W plateau exercise. The patient was able to sustain the exercise for $7 \mathrm{~min}$ but had difficulty in continuously reaching the right level. At the end of the exercise, ventilation was equal to $19.5 \mathrm{~L} / \mathrm{min}$, respiratory exchange ratio was 1.31 , and $\mathrm{VO}_{2}$ leveled at $11.3 \mathrm{~mL} / \mathrm{min} / \mathrm{kg}$ body weight, which is very low compared with control values for healthy, untrained young boys (i.e. $\mathrm{VO}_{2}=37 \pm 2 \mathrm{~mL} / \mathrm{min} / \mathrm{kg}$ ).

The patient's venous resting lactate and pyruvate were high at $3.65 \mathrm{mM}$ and $398 \mu \mathrm{M}$, respectively, and the $\mathrm{L} / \mathrm{P}$ ratio was 9.3 , which is in the normal range (control level: lactate, $1.1 \pm 0.3$ $\mathrm{mM}$, pyruvate, $90 \pm 22 \mu \mathrm{M}$, and $\mathrm{L} / \mathrm{P}$ ratio, $12.9 \pm 3.3$ ).

At the end of the exercise period, the lactate and pyruvate concentrations increased considerably, reaching $13.6 \mathrm{mM}$ for 
Table 1. Pretreatment and posttreatment respiratory and metabolic results, at rest and after a maximal exercise test*

\begin{tabular}{lccrrr}
\hline & $\begin{array}{c}\mathrm{HR} \\
(\mathrm{b} / \mathrm{min})\end{array}$ & $\begin{array}{c}\mathrm{VO}_{2} / \mathrm{kg} \\
(\mathrm{mL} / \mathrm{min} / \mathrm{kg})\end{array}$ & $\begin{array}{r}\mathrm{LACT} \\
(\mathrm{mM})\end{array}$ & $\begin{array}{l}\text { PYR } \\
(\mu \mathrm{M})\end{array}$ & $\mathrm{L} / \mathrm{P}$ \\
\hline Rest & & & & & \\
$\quad$ Pretreatment & 108 & & 3.65 & 398 & 9.3 \\
$\quad$ Posttreatment & 80 & & 1.12 & 76 & 14.7 \\
Control values $(n=25)$ & 70 & & 1.10 & 90 & 12.9 \\
$\quad$ SD & & & \pm 0.30 & \pm 22 & \pm 3.3 \\
Maximum exercise & & & & & \\
$\quad$ Pretreatment & 180 & 11.3 & 13.60 & 537 & 24.2 \\
Posttreatment & 164 & 25.0 & 2.11 & 94 & 22.4 \\
Control values $(n=25)$ & 180 & 37.0 & 6.40 & 176 & 35.0 \\
SD & & \pm 2.0 & \pm 1.30 & \pm 15 & \pm 2.0 \\
\hline
\end{tabular}

* The exercise test was performed by using an Astrand children's cycle ergometer. At rest and during the last minutes of work load, respiratory parameters were measured using a Gould 9000 cardiopulmonary exercise system. Venous (antecubital) blood was collected at rest and at the end of the exercise test. HR, heart rate; LACT, lactate; PYR, pyruvate. The treatment was thiamine $500 \mathrm{mg} / \mathrm{d}+$ carnitine $200 \mathrm{mg} / \mathrm{d}$ for $1 \mathrm{y}$.

Table 2. $\mathrm{VO}_{2}$ in muscle mitochondria from patient and controls with different substrates*

\begin{tabular}{lrrrrrr}
\hline & \multicolumn{2}{c}{$\mathrm{VO}_{2}$} & & \multicolumn{2}{c}{$\mathrm{RCR}$} \\
\cline { 2 - 3 } \cline { 6 - 7 } & Patient & $\begin{array}{c}\text { Controls } \\
(n=10) \dagger\end{array}$ & & Patient & $\begin{array}{c}\text { Controls } \\
(n=10) \dagger\end{array}$ \\
\hline Malate + glutamate & 70 & $114 \pm 39$ & & 3.8 & $5.1 \pm 1.6$ \\
Malate + palmitoylcarnitine & 131 & $109 \pm 31$ & & 3.3 & $3.6 \pm 1.3$ \\
Malate + pyruvate & 17 & $115 \pm 42$ & & 1.0 & $4.9 \pm 2.1$ \\
+ glutamate & 70 & $114 \pm 39$ & & 2.3 & $5.1 \pm 1.6$ \\
Malate + pyruvate & 24 & $115 \pm 42$ & & 1.0 & $4.9 \pm 2.1$ \\
+ palmitoylcarnitine & 92 & $109 \pm 31$ & & 3.7 & $3.6 \pm 1.3$ \\
Succinate & 118 & $109 \pm 32$ & & 1.7 & $2.2 \pm 0.7$ \\
\hline
\end{tabular}

* $\mathrm{VO}_{2}$, measured at $25^{\circ} \mathrm{C}$ in the presence of ADP (state 3 ), is expressed in $\mathrm{ng}$ atoms $\mathrm{O} / \mathrm{min} / \mathrm{mg}$ mitochondrial proteins.

$\uparrow$ Values shown include $\mathrm{SD} ; n=$ number of determinations.

lactate and $537 \mu \mathrm{M}$ for pyruvate; the $\mathrm{L} / \mathrm{P}$ ratio was 24.2 . At maximal power in the control group of young boys, lactate, pyruvate, and $\mathrm{L} / \mathrm{P}$ ratio were $6.4 \pm 1.3 \mathrm{mM}, 176 \pm 15 \mu \mathrm{M}$, and $35 \pm 2$, respectively.

Posttreatment results. One y of treatment of the patient with thiamine and L-carnitine normalized his resting metabolic parameters. He was able to sustain an exercise level corresponding to a $\mathrm{VO}_{2}$ of $25 \mathrm{~mL} / \mathrm{min} / \mathrm{kg}$. At this level of exercise, lactate, pyruvate, and $\mathrm{L} / \mathrm{P}$ ratio (Table 1 ) increased only mildly.

Biochemical Results. Oxidation of substrates by intact mitochondria. The freshly isolated muscle mitochondria were incubated with different substrates, and oxygen uptake was measured in the presence and after consumption of ADP (Table 2). The patient's muscle mitochondria actively oxidized glutamate, palmitoylcarnitine, and succinate and showed normal RCR with these substrates. However, the RCR with pyruvate was very low, as the patient's muscle mitochondria were unable to oxidize pyruvate. Contamination by a respiratory inhibitor during pyruvate assay could be eliminated, because normal values were recovered when glutamate or palmityolcarnitine were added.

Enzymatic Assays. We therefore investigated the PDH activity in fresh mononuclear cells and in the homogenate and purified mitochondria from muscle (Table 3). Total PDH activity was measured after activation of the endogenous PDH phosphatase by high levels of $\mathrm{Ca}^{++}$and $\mathrm{Mg}^{++}$. The results obtained for controls were in a range similar to that of those obtained after incubating cells with dichloroacetate (25). The activity of the stimulated, i.e. total, PDH in lymphocytes and muscle (homogenate and mitochondria) was lower than $20 \%$ in both tissues compared with
Table 3. Total PDHC activity in PMC and in muscle preparations*

\begin{tabular}{lccc}
\hline & & \multicolumn{2}{c}{ Muscle } \\
\cline { 3 - 4 } & PMC & Homogenate & Mitochondria \\
\hline Controls $\dagger$ & $0.733 \pm 0.03$ & $2.25 \pm 0.18$ & $123.0 \pm 4.5$ \\
Patient, pretreatment & 0.054 & 0.407 & 9.70 \\
Residual activity & $7 \%$ & $8 \%$ & $18 \%$ \\
Patient, posttreatment & 0.042 & ND & ND \\
Residual activity & $6 \%$ & & \\
\hline
\end{tabular}

* Activities are expressed in $\mathrm{nmol} / \mathrm{min} / \mathrm{mg}$ protein. PDH activity was measured with $1-{ }^{14} \mathrm{C}$ pyruvate as substrate (see Materials and Methods) in sonicated preparations of $\mathrm{PMC}$, in homogenate, and in mitochondria of muscle from the patient. ND, not determined.

$\uparrow$ Values are mean \pm SD $(n=11$ for PMC and 4 for muscle preparations).

$\ddagger$ Values shown are the mean of duplicate determinations.

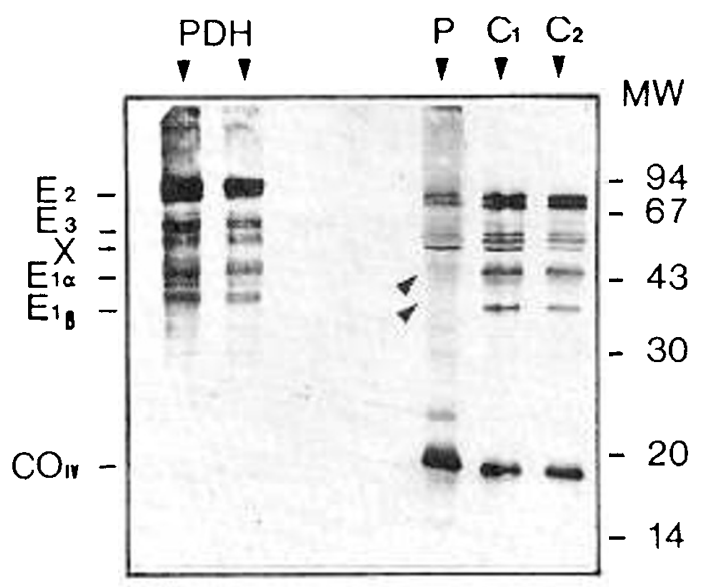

Fig. 1. Immunoblot pattern of PDHC (E1 $\alpha, \mathrm{E} 1 \beta, \mathrm{E} 2, \mathrm{E} 3$, and $\mathrm{X}$ proteins) from muscle mitochondria revealed with anti-PDHC antibody from bovine heart. Antibody raised against subunit IV of purified human heart cytochrome $c$ oxidase was used as control $(C O I V)$. Mitochondrial extracts (10- $\mu$ g proteins) from muscle of patient $(P)$ and of two controls $\left(C_{1}\right.$ and $\left.C_{2}\right)$ were analyzed on $15 \%$ SDS polyacrylamide gel. Immunoreactive proteins were visualized by using ${ }^{35} \mathrm{~S}$-labeled goat anti-rabbit IgG $(0.3 \mu \mathrm{Ci} / \mathrm{mL})$.

control values, contrasting with the relatively good clinical state. The percentage of PDH present in the active form (without endogenous PDH phosphatase activation) out of the total PDH activity (with PDH phosphatase activation) was $17 \%$ for the patient and 10 to $20 \%$ for control values. Other enzymes of the respiratory chain measured in patient's muscle mitochondria, i.e. cytochrome $c$ oxidase, succinate cytochrome $c$ reductase, and citrate synthase, had normal activities within the normal-range values $(3872,363$, and $2108 \mathrm{nmol} / \mathrm{min} / \mathrm{mg}$ protein, respectively; controls: $2582 \pm 626,534 \pm 206$, and $2153 \pm 402$, respectively).

Immunologic Analysis of PDHC Components. Figure 1 shows that the antibodies prepared with purified bovine heart PDHC cross-react with human PDHC subunits. Immunologic analysis of muscle mitochondria of the patient and of two controls with normal PDH activity and of purified bovine heart PDH was carried out with anti-PDHC antibody (Fig. 1). In our electrophoresis conditions, the E2 protein appeared to have a molecular mass of $74 \mathrm{kD}$, the $\mathrm{X}$ protein $50 \mathrm{kD}$, and the subunits $\alpha$ and $\beta$ E1 proteins 44 and $38 \mathrm{kD}$, respectively. Muscle mitochondria from the patient exhibited noticeably decreased amounts of E2 and E3 subunits of the PDHC, and the $\mathrm{X}$ protein appeared normal; E1 did not appear on the immunoblot. The same quantity of mitochondrial proteins was used in each lane of the gel (i.e. patient and control), as shown by the similar immunoreaction observed with polyclonal antibodies against subunit IV of purified human heart cytochrome $c$ oxidase, used as control. 
Genetic Analysis of PDH El $\alpha$. Exons 10 and 11 of PDH E $1 \alpha$ were cloned in pUC18 after genomic amplification of the patient's DNA using specific synthetic oligonucleotide primers. Sequencing of both exons did not reveal any abnormality compared with the known cDNA sequences (26).

\section{DISCUSSION}

The case described here corresponds to a very rare category of patients having PDH deficiency, with initial hypotonia, weakness, and a mild lacticacidemia that disappeared after supplementation with thiamine. A clinically similar case, described by Endo et al. (11), is not consistent with the classical clinical presentations of PDHC deficiency $(4,27)$. It is generally found that patients with less than 10 to $20 \%$ of normal values of PDH activity present with lactic acidosis and severe neurologic symptoms, whereas patients with 40 to $50 \%$ residual activity have a milder illness. An intermittent ataxia is the most important neurologic symptom in this latter group.

The patient here had mild clinical features associated with motor neuropathy, without cerebral or cerebellar dysfunction, developed during a postvaccination period in the first attack (at 18-mo of age) and during an infectious episode in the second attack (at $3 \mathrm{y}$ of age). The first exercise test, performed at $7 \mathrm{y}$ of age, showed an important limitation of the global metabolic oxidation accompanied by a clear increase of blood lactate and pyruvate values, as compared with those obtained in the control group of young boys. The second exercise test, after 1 y of treatment with thiamine and carnitine, demonstrated an improvement of the metabolic state of the patient, consistent with the clinical improvement. His resting blood values for lactate, pyruvate, and $\mathrm{L} / \mathrm{P}$ ratio were in the normal range. The exercise test showed an important increase in the oxidation, which was multiplied by 2.2 with no development of acidosis. At this level of exercise, which represented roughly $70 \%$ of control maximal $\mathrm{VO}_{2}$, his production of muscular energy was mainly aerobic, as in the controls. Before thiamine treatment, the biochemical defect of PDH was suspected because of the inability of isolated muscle mitochondria of the patient to oxidize pyruvate, whereas other mitochondrial enzymes were in the normal range, as previously described for a patient with a severe PDHC deficiency (27). These results were confirmed by the low level of total PDH activity found in muscle mitochondria (about $8 \%$ ). This low activity was not due to a loss of activity occurring during the purification of mitochondria, because PDH activity was also found to be low (about 20\% of normal) in muscle homogenate. This defect was also expressed in fresh mononuclear cells with a similar residual activity as compared with muscle mitochondria, suggesting that mononuclear cells could reflect the severity of systemic PDHC deficiency. The defect appeared to be in the PDH E1 component because, in the PDH activity assay, E2 was added in the medium, and E3 was not a limiting step for other mitochondrial decarboxylases. Although the residual activity of $\mathrm{PDH}$ in fresh lymphocytes was very low, the relative extent of activation of endogenous $\mathrm{PDH}$ phosphatase by $\mathrm{MgCl}_{2}$ and $\mathrm{CaCl}_{2}$ was in normal range. This suggests that a primary defect of this regulatory enzyme was not involved. The residual enzyme activity was confirmed by the immunochemical analysis of PDHC subunits from muscle mitochondria of the patient; the E1 $\alpha$ and $\mathrm{E} 1 \beta$ were virtually undetectable and $\mathrm{E} 2$ and $\mathrm{E} 3$ decreased, as compared with controls. To our knowledge, until now, only two patients presenting a mild lacticacidemia and hypotonia and weakness that disappeared after supplementation with thiamine $(11,28)$ have been described. In these cases, a low PDH activity ranging from $25 \%$ of the normal in patient 1 (11) and $50 \%$ in patient 2 (patient no. 5 of ref. 28) was found in cultured skin fibroblasts. The immunochemical analysis that was performed in the different cells and tissues of the preceding two cases has demonstrated different patterns: in patient 1 , the $\mathrm{E} 1 \alpha$ band of PDHC of lymphoblastoid cells was missing and, instead, an additional band was detected below protein $X$. However, in patient 2, the amount of $\mathrm{E} 1 \alpha$ subunit in fibroblasts was comparable to that in control, but its electrophoretic mobility was altered. A different immunoblot pattern was observed in the muscle mitochondria of our patient, i.e in which the $\mathrm{E} 1 \alpha$ and $\beta$ were undetectable and E2 and E3 were decreased.

Most of the PDH E1 deficiencies are due to a mutation of $\mathrm{E} 1 \alpha$ gene located in the $\mathrm{p} 22.1$ to $\mathrm{p} 22.2$ region of the $\mathrm{X}$ chromosome $(9,10)$. Different mutations have been described in patients with PDH E1 deficiency, in particular in exon 10 or exon 11 (11-13). In our patient, no mutation was found in these two exons.

TPP is a cofactor of the PDHC. Our patient did not suffer from thiamine deficiency, inasmuch as a thiamine deficiency should have affected the metabolism of glutamate via the $\alpha$ cetoglutarate dehydrogenase, a multicomplex with a thiaminedependent enzyme like PDHC. Polarographic data (Table 2) showed that glutamate is normally metabolized by the patient's muscle mitochondria. Thiamine pyrophosphate is added in excess during the enzymatic assay. The low activity in our patient was not improved by TPP addition examined in fresh lymphocytes both before and after 1 y of thiamine therapy (Table 3 ). The beneficial effect of thiamine is only visible in vivo, as seen by the improvement of the clinical features and by the metabolic parameters tested during the second exercise test. This discrepancy, between the absence of response to TPP addition observed in vitro on lymphocytes and the clinical improvement in vivo by the thiamine therapy, could be explained by an instability of the $\mathrm{PDH}$ complex in vitro (proteolysis of $\mathrm{E} 1 \alpha$ and $\mathrm{E} 1 \beta$ subunits), whereas in vivo the PDH complex seems more stable with the addition of the cofactor. A mutation could have occurred in the $\mathrm{E} 1 \alpha$ gene in another region, particularly in the exon 8 coding for the TPP binding site (29), causing a decrease in the binding of this cofactor, thereby leading to a degradation of $\mathrm{E} 1 \alpha$ and $\mathrm{E} 1 \beta$ subunits. This patient, although similar to the patient studied by Endo et al. (11) at the clinical and biochemical level, is genetically different and therefore is an original case of PDHC deficiency.

Additional investigations to search for any mutation(s) in TPP binding site (29) and PDHE $\alpha$ or PDHE1 $\beta$ genes are underway.

Acknowledgments. The authors thank F. Demaugre (INSERM U 75, Paris, France) and S. V. Pande (Institut de Recherche Clinique de Montréal, Montreal, Canada) for helpful discussions, Professor B. Kadenbach (Biochemie, University of Marburg, Germany) for the kind gift of polyclonal antibodies against purified human heart cytochrome $c$ oxidase, and D. François (INSERM U 75, Paris, France) for his participation in this work.

\section{REFERENCES}

1. Reed LJ 1974 Multienzyme complexes. Accounts Chem Res 7:40-46

2. Neagle JC, Kindsay G 1991 Selective proteolysis of the X subunit of the bovine heart pyruvate dehydrogenase complex. Biochem J 278:423-427

3. Linn TC, Pettit FH, Reed LJ $1969 \alpha$-Keto acid dehydrogenase complexes. X. Regulation of the activity of the pyruvate dehydrogenase complexes from beef kidney mitochondria by phosphorylation and dephosphorylation. Proc Natl Acad Sci USA 62:234-241

4. Robinson BH, MacMillan H, Petrova-Benedict R, Sherwood WG 1987 Variable clinical presentation in patients with defective E1 component of the pyruvate dehydrogenase complex. J Pediatr 111:525-533

5. Brown GK, Haan EA, Kirby DM, Scholem RD, Wraith JE, Rogers JG, Danks DM 1988 "Cerebral" lactic acidosis: defects in pyruvate metabolism with profound brain damage and minimal systemic acidosis. Eur J Pediatr 147:10 14

6. Blass JP 1983 Inborn errors of pyruvate metabolism. In: Stanbury JB, Wyngaarden JB, Frederickson DS, Goldstein JL, Brown MS (eds) The Metabolic Basis of Inherited Diseases, 5th ed. McGraw Hill, New York, pp 193-203

7. Robinson BH, Taylor J, Sherwood WG 1980 The genetic heterogeneity of lactic acidosis: occurence of recognizable inborn errors of metabolism in a pediatric population with lacticacidosis. Pediatr Res 14:956-962

8. McKay N, Petrovna-Benedict R, Thoene J, Bergen B, Wilson W, Robinson B 1986 Three cases of lactic acidemia due to pyruvate decaroxylase (E1) deficiency with evidence of protein polymorphism in the $\alpha$ subunit of the enzyme. Eur J Pediatr 144:445-450

9. Brown RM, Dahl H-HM, Brown GK 1989 X-chromosome location of the functional gene for the $\mathrm{El} \alpha$ subunit of the human pyruvate dehydrogenase complex. Genomics 4:174-181 
10. Maragos C, Hutchinson WM, Hayasaka K, Brown GK, DahI HH 1989 Structural organization of the gene for the El $\alpha$ subunit of the human pyruvate dehydrogenase complex. J Biol Chem 264:12294-12298

11. Endo H, Hasegawa K, Narisawa K, Tada K, Kagawa Y, Ohta S 1989 Defective gene in lactic acidosis: abnormal pyruvate dehydrogenase $E 1 \quad \alpha$-subunit caused by a frame shift. Am J Hum Genet 44:358-364

12. Dahl H-H, Maragos C, Brown RM, Hausen LL, Brown GK 1990 Pyruvate dehydrogenase deficiency caused by deletion of a 7 -bp repeat sequence in the El $\alpha$ gene. Am J Hum Genet 47:286-293

13. Chun K, MacKay N, Petrova-Benedict R, Robinson BH 1991 Pyruvate dehydrogenase deficiency due to a 20 -bp deletion in exon 11 of the pyruvate dehydrogenase (PDH) El $\alpha$ gene. Am J Hum Genet 49:414-420

14. Brown GC 1992 Control of respiration and ATP synthesis in mammalian mitochondria and cells. Biochem J 284:1-13

15. Boyum A 1968 Isolation of mononuclear cells and granulocytes from human blood. J Clin Lab Invest 97:77-89

16. Morgan-Hughes JA, Darveniza P, Khan SN, Landon DN, Sherratt RM, Land JM, Clark JB 1977 A mitochondrial myopathy characterized by a deficiency in reducible cytochrome b. Brain 100:617-640

17. Degoul F, Nelson I, Lestienne P, François D, Romero N, Duboc D, Eymard B, Fardeau M, Ponsot G, Paturneau-Jouas M. Chaussain M, Leroux JP, Marsac C 1991 Deletions of mitochondrial DNA in Kearns-Sayre syndrome and ocular myopathies: genetic, biochemical and morphological studies. J Neurol Sci 101:168-177

18. Seals JR, Jarett L 1980 Activation of pyruvate dehydrogenase by direct addition of insulin to an isolated plasma membrane/mitochondria mixture evidence for generation of insulin's second messenger in a subcellular system. Proc Natl Acad Sci USA 77:77-81
19. Clot JP, Benelli C, Fouque F, Bernard R, Durand D, Postel-Vinay MC 1992 Pyruvate dehydrogenase activity is stimulated by growth hormone in human mononuclear cells: a new tool to measure GH responsiveness in man. J Clin Endocrinol Metab 74:1258-1262

20. Cooperstein SJ, Lazarow A 1951 A microspectrophotometric method for the determination of cytochrome oxidase. J Biol Chem 189:665-670

21. Laemmli UK 1970 Cleavage of structural proteins during assembly of the head of bacteriophage T4. Nature 227:680-685

22. Maniatis T, Fritsch EF, Sambrook J 1982 Molecular Cloning: A Laboratory Manual. Cold Spring Harbor Laboratory, Cold Spring Harbor, NY

23. Saiki RK, Gelfand DH, Stoffel S, Scharf SJ, Higuchi R, Horn GT, Mullis KB, Erlich HA 1988 Primer-directed enzymatic amplification of DNA with a thermostable DNA polymerase. Science 239:487-491

24. Sanger F, Nicklen S, Coulson AR 1977 DNA sequencing with chain-terminating inhibitors. Proc Natl Acad Sci USA 74:5463-5467

25. Kerr DS, Berry SA, Lust MM, Ho L, Patel MS 1988 A deficiency of both subunits of pyruvate dehydrogenase which is not expressed in fibroblasts. Pediatr Res 24:95-100

26. De Meirleir L, MacKay A, Lam Hon Wah AM, Robinson B 1988 Isolation of a full-length complementary DNA coding for human E1 $\alpha$ subunit of the pyruvate dehydrogenase complex. J Biol Chem 263:1991-1995

27. Kerr DS, Ho L, Berlin CM, Lanoue KF, Towfighi J, Hoppel CL, Lusk MM, Gondek CM, Patel MS 1987 Systemic deficiency of the first component of the pyruvate dehydrogenase complex. Pediatr Res 22:312-318

28. Old SE, De Vivo DC 1989 Pyruvate dehydrogenase complex deficiency: biochemical and immunoblot analysis of cultured skin fibroblasts. Ann Neurol 26:746-751

29. Hawkins CF, Borges A, Perham RN 1989 A common structural motif in thiamine pyrophosphate binding enzymes. FEBS Lett 255:77-82

\section{Announcement}

\section{Annual Meetings}

The American Pediatric Society, The Society for Pediatric Research, and The Ambulatory Pediatric Association will hold their annual meetings May 3-6, 1993 at the Sheraton Washington Hotel, Washington, DC. For further information, contact: APS/SPR Association Headquarters, 141 Northwest Point Blvd., P.O. Box 675, Elk Grove Village, IL 60009-0675, (708) 427-0205, FAX (708) 427-1305 or Ambulatory Pediatric Association, 6728 Old McLean Village, McLean, VA 22101, (703) 556-9222, FAX (703) 556-8729. 